\title{
River Conservation Using SECEEL Approach: A Case Study on East Flood Way River, Semarang, Central Java, Indonesia
}

\author{
Ignatius Sriyana ${ }^{1, *}$ \\ ${ }^{1}$ Lecturer in Civil Engineering Department, Faculty of Engineering, Diponegoro University, \\ Tembalang Campus, Semarang, Indonesia 50275
}

\begin{abstract}
Current practices on river conservation are solely depending on social engineering, cultural, economic and environmental approaches without taking law enforcement into account. This issue becomes critical because river conservation is frequently experiencing conflict without assertive law enforcement. One of the cases is the presence of abundant structures on river bank despite of rules against such practices. This violation is rooted on law enforcement aspect. Therefore, integrated approach incorporating law enforcement is important to be studied. The purpose of this study is to test the effect of this integrated approach named Social Engineering, Culture, Economic, Environment comfort and Law enforcement (SECEEL) against river conservation on river bank. The analysis method is quantitative approach using Partial Least Squares Structural Equation Modeling (PLS - SEM) program involving 150 respondents as a sample of approximately 400 habitants in East Flood Way river, Semarang. The result shows that higher social engineering value and economic expediency together with lower rule of law are creating higher environment comfort level along the river bank. Meanwhile, more positive cultural values will decrease the level of environment comfort on the area. Interestingly, the higher the comfort level of the environment along the river will decrease the value of conservation.
\end{abstract}

\section{Introduction}

As stipulated in Indonesian Government Regulation (PP) No. 38 Year 2011, Chapter 2 Article 5 Verse 4 and 5, the river functions as a path for running water and as a venue for the life of river ecosystems. Furthermore, riverbanks act as a buffer space for river and land ecosystems that prevent disruption between each other [1]. To promote optimal river utilization, it is necessary to manage the river in a proper way, one of which is to carry out river conservation which includes river protection and the prevention of river water pollution in a sustainable manner involving the community and the government [2]. If the river management is carried out appropriately then the results would be more effective and sustainable [3].

*Author: sriyana808@gmail.com 
Some problems on the river management are causing violations in the riverbanks, the diminishing dimension of the embankment due to human activities and waste disposal to the river resulted in pollution of river water and disruption of water flow. These existing problems are caused by low public awareness and lack of attention regarding river conservation's implementation. This violation can adversely affect the continuity of the river in the future, which in turn will be detrimental to human's life.

Current practices on river conservation are only utilizing social engineering, cultural, economic [4] and environmental comfort approaches without taking into account law enforcement variable. This issue becomes a critical point because river conservation implementations are frequently experiencing conflict without assertive law enforcement [5]. On the field, warning signs for prohibiting community to build structure on river bank area have already installed, however, violations are still abundant. Integrated approach incorporating social engineering, cultural, economic, environment comfort and law enforcement is important to be studied.

The purpose of this research is to test SECEEL (Social Engineering, Culture, Economic, Environment comfort and Law enforcement) approach against conservation value on river banks. Several parameters are tested, including the effect of economic benefits, social values, cultural values and law enforcement to the environment comforts.

\section{Materials and Research Method}

\subsection{Research Location}

The research location is in East Flood Way (Banjir Kanal Timur) river in Semarang of approximately $2 \mathrm{~km}$ in length and the width of 174 meters (including riverbank). The northern boundary coordinates are at $\mathrm{x}=438560, \mathrm{y}=9230059$, eastern boundary at $\mathrm{x}=$ 438462, $\mathrm{y}=9228616$, southern boundary at $\mathrm{x}=437955, \mathrm{y}=9226296$ and western boundary at $\mathrm{x}=438239, \mathrm{y}=9228304$.

The data used are basic map in the form of administrative map, satellite image, river map along with river area (based on Government Plan on Spatial and Territory Utilization of Semarang City for 2017) and field survey on 2017.

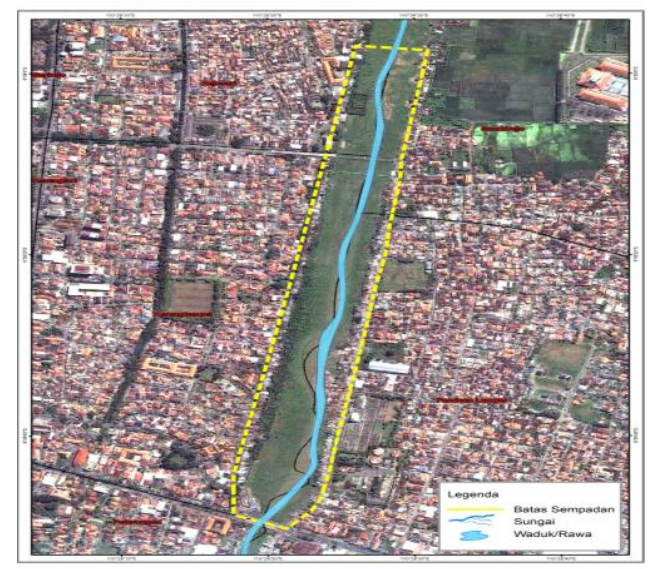

Fig. 1. Map of East Flood Way. 


\subsection{Research Method}

The analysis method used in this research was quantitative methods using software PLS SEM.3.0 [6]. The stages of this study included preparation stage (field orientation, building questionnaires, etc.), data collection phase of both primary and secondary data, data processing and continued data analysis.

Researcher directly observed and interviewed the residents of the river using questionnaires to obtain primary data. Number of respondents involved was 150 respondents compared to the population of approximately 400 respondents located along the East Flood Way (Banjir Kanal Timur) river. Meanwhile, the secondary data was obtained from the Ministry of Public Works and Public Housing, Directorate General of Water Resources, Major River Basin Pemali - Juana Region in Semarang.

\section{Analyses and Discussion}

SECEEL approach, which tests the effect of economic benefit, social values, cultural values of society and law enforcement to the comfort of the environment on river banks and the influence of comfort to the river conservation value, is using multivariate statistical analysis including convergence validity test, discriminant validity test, construct reliability test, path and hypothesis testing analysis (see Fig. 2 below).

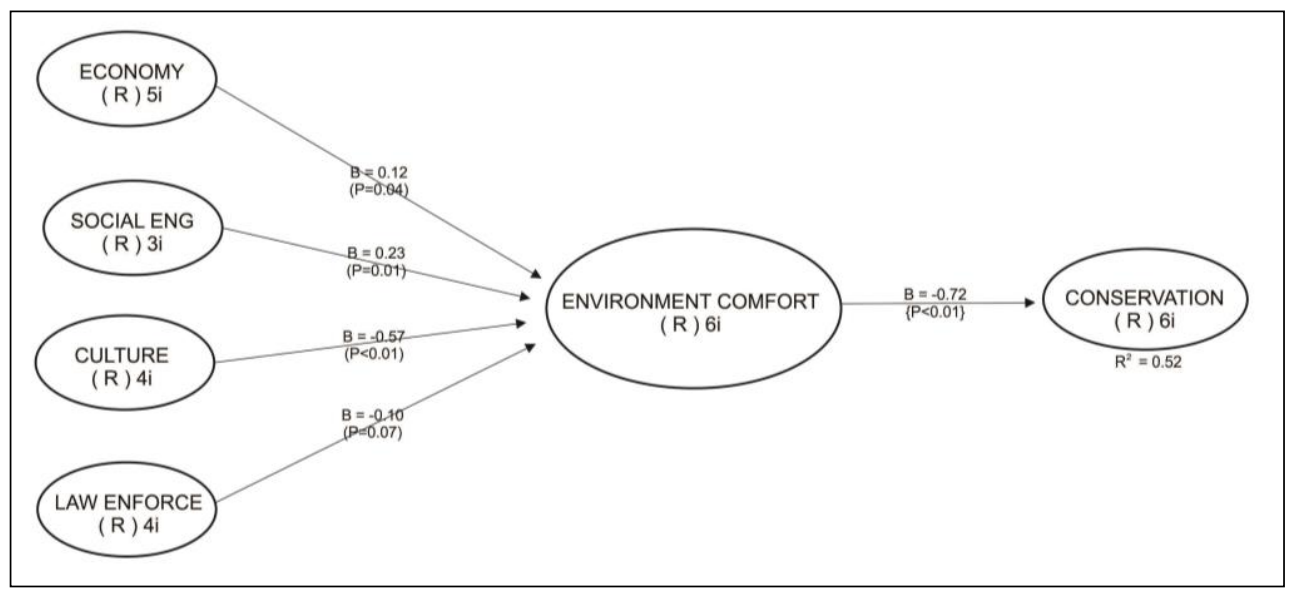

Fig. 2. Diagram of multivariate statistical analysis.

Based on Fig. 2, it can be interpreted that the model and coefficient values contained in the diagram are fit $(\mathrm{APC}=0.348, \mathrm{P}<0.001$, ARS $=0.740, \mathrm{P}<0.001$ and $\mathrm{AVIF}=6.258$, Good if <5), it means the model is appropriate for the analytical tool in the study. Variations of predictor variables (Economic, Social, Cultural and Legal) may account for $96 \%$ of variation in criterion variables (Environment Comfort). Meanwhile, variations in the predictor variables of environment comfort account for $52 \%$ of variation in the conservative criterion variables. The following analysis results are obtained from the software.

The first hypothesis stating that the greater the economic benefits that can be enjoyed, the higher the level of environment comfort in the East Flood Way river is proven $(\mathrm{p}=0.04$ $<0.05$ ). This is apparent that in the river banks, street traders have built kiosks which are used to run several businesses like car workshop, salon, shops, radio service, vegetable traders, bird merchants, etc. This has violated Indonesian Government Regulation (PP) no. 
38 year 2011, article 22, verse 2, which state within the river border, there are embankments for the interest of flood control. Protection of embankment bodies is done by prohibiting the planting of plants other than grass, erecting buildings and reducing dimension of the embankment.

The second hypothesis states that the higher the social value, the higher the level of environment comfort in the riverbanks of the East Flood Way river is proven $(p=0.01 \leq$ 0.05). The residents at the research sites appear to have strong ties, mutual cooperation spirit, hand in hand, helpful mind and have formed the board of neighborhood, where the people from outside follows the citizens who occupy riverbanks. It tends to cause social unrest in the time of executing the river conservation program.

The third hypothesis states that the more positive the cultural values of the environment, the lower the comfort level in the East Flood Way river is proven $(p=0.01<0.05)$. This is evidenced that most residents of riverbanks have built a negative culture of dumping domestic waste in the river for their comfort. This act will pollute the river and clearly violating Government Regulation (PP) no. 38 year 2011, article 27 and paragraph 1.

The fourth hypothesis states that the lower the law enforcement, the higher the level of environment comforts in the riverbanks of the East Flood Way river is proven ( $p=0.07$ $<0.1$, significant with $\alpha=0.1$ ) [7]. It shows the weakness of law enforcers in implementing sanctions for perpetrators who have committed violations to the river management rule.

The fifth hypothesis stating that the higher level of environment comfort in river banks will further decrease conservation value is proven $(\mathrm{p}=0.01<0.05)$. The impact will be in the form of potential conflict on implementing river conservation, either river protection or river pollution prevention activities, against the environment therefore require greater costs to overcome them.

\section{Conclusions and Recommendations}

\subsection{Conclusions}

Based on the analysis and discussion above, it can be concluded as follows:

1. SECEEL approach showed that the more economic benefits that can be enjoyed and the higher the social value resulted in the higher the level of environment comfort, the more positive the cultural value of the environment will be lower the comfort level, the lower the law enforcement will be resulting in high level of environment comfort, and the higher the level of environmental comfort on the river banks will further diminish the value of conservation.

2. Persistently weak law enforcement in implementing sanctions for perpetrators who have committed violations against river management rule is proven to be one of detrimental factor on river conservation.

3. Lack of attention on means of supporting the implementation of river management activities by the Government.

\subsection{Recommendations}

Below are several recommendations in order to realize the sustainability of river functions:

1. Law enforcement must act assertively, as early as possible, in gradual manner sequencing first, second and final warning letter in case of violation of the law (e.g. erecting building on river banks, dumping in rivers, etc.).

2. Routine river management needs to be carried out, for example, protection and prevention of river pollution activities, by involving the community. 
3. There needs to be cooperation and mutual coordination between the government (Central, Provincial and District/City) in implementing river management in accordance with their respective authorities.

The author wishes to express sincere gratitude to Water Resources Laboratory, Civil Department, Faculty of Engineering, Diponegoro University for allowing the author to use the laboratory facilities. Same gratitude is addressed to the Ministry of Public Works and Public Housing, Directorate General of Water Resources, Major River Basin Organization Pemali - Juana Region in Semarang for providing data needed in this study.

\section{References}

1. Indonesian Government Regulation (PP) No. 38 Year 2011 about "River"

2. J. S. Antunes do Carmo, Natural Responses to Changes in Morphodynamic Processes Caused by Human Action in Watercourses: A Contribution to Support Management, International Journal of Disaster Risk Reduction, 24, 109-118 (2017)

3. M. A. Evans, J. Hall, E. Penning-Rowsell, P. Sayers, C. Thorne and A. Watkinson, Future Flood Risk Management in the UK, Proceedings of the Institution of Civil Engineers Water Management 159, 53-61 (2006)

4. C. Spörri, M. Borsuk, I. Peters, P. Reichert, The Economic Impacts of River Rehabilitation: A Regional Input-Output Analysis, Ecological Economics 62, Issue 2, 341-351 (2007)

5. P. J. Cosgrove, L. C. Hastie, Conservation of Threatened Freshwater Pearl Mussel Populations: River Management, Mussel Translocation and Conflict Resolution, Biological Conservation 99, Issue 2, 183-190 (2001)

6. I. Ghozali, Model Persamaan Struktural: Konsep dan Aplikasi dengan Program AMOS19.0 (2002)

7. C. J. Barrow, River Basin Development Planning and Management: A Critical Review, World Development 26, No. 1, 171-186 (1998) 